\title{
Evaluating pricing policies applied to Tour Operators and Travel Agents in Egypt
}

\author{
Salama A. M. Ammar
}

Higher Institute for Tourism and Hotels (EGOTH), Luxor, Egypt

\begin{abstract}
This study evaluates the pricing policies adopted by Tour Operators/Travel Agents in Egypt. The field study was conducted through distributing a questionnaire to managers of Tour Operators/Travel Agents. The sample included 51 Tour Operators/Travel Agents managers. The pricing techniques applied at Tour Operators/Travel Agents have high levels of efficiency and sensitivity .The training programs influences significantly the efficiency of pricing techniques. There is a strong relation between the sensitivity of pricing techniques and the efficiency of pricing technique applied at Tour Operators/Travel Agents. The study provides some recommendations such as: applying the suitable pricing strategy for Tour Operators/Travel Agents conditions; assigning an effective link between the price and the other factors of the marketing mix to be more competitive
\end{abstract}

Keywords: pricing policies/techniques, pricing efficiency, Tour Operators/Travel Agents

\section{Introduction:}

Pricing policies and techniques are very important components of the daily operations of services organizations. This is because price is one of the most effective variables that managers can manipulate to encourage or discourage demand for services and products in the short-run (Aziz et al., 2011; Gazopoulou, 2012). In many tourist destinations, tourism intermediaries (including tour operators and travel agents) play an important role in setting the prices that consumers should pay for tourism products and services, particularly in destinations which depend on intermediaries (Buhalis, 2000).

Pricing policy is very important for the market success of travel agencies offering products of tourism (Kyurova, 2013). Ineffective implementation of pricing policies can result in a decline in both domestic and international tourism demand and unless the pricing policies are well applied, the tourism industry in the developing countries will lose the economic benefits that could result from tourism (Walpole, Goodwin \& Ward, 2008).

Therefore, this study aims to explore the pricing policies and techniques applied at tour operators and travel agents in Egypt; as well as to evaluate the efficiency of these policies and techniques. It also aims to provide some recommendations to managers of tour operators and travel agents in Egypt to enhance their performance regarding the integration of policies and techniques.

\section{Literature review:}

\section{Pricing policies and techniques for tourism services:}

Pricing is the process of setting values at which products and services are to be sold. Thus, pricing is an important process to the successful marketing of products or services (Buhalis, 2000; Hudson, 2008; Reid \& Bojanic, 2009). Also, price is a main measure that customers use for judging the value of the product and it strongly in fluencies brand selections among competing organizations (Avlontis \& Indounas, 2007). In addition, pricing is the only element of the marketing mix that generates revenues for the company whilst the other elements of the mix represent costs (Lancaster \& Reynolds, 2005).

According to Kyurova (2013) the pricing policy of an organization refers to the process of setting prices and their fluctuating levels on the short and long term depending on the market conditions. There are several policies/techniques that can be used for pricing tourism services; each of which has its own characteristics, advantages and disadvantages (Buhalis, 2000; Reid \& Bojanic, 2009). Pricing strategies/policies of tourist products and services may include strategies such as: skimming pricing strategy; penetration pricing strategy; neutral pricing strategies (Reid \& Bojanic, 2009). According to skim pricing strategy, prices of products and services are set very high with high quality to attract rich tourists to achieve high profit out of these certain exclusive segments. However, penetration pricing strategy involves setting prices that attract more customers and gain advantage over its competitors. According to neutral pricing strategy, prices are to 
be set at moderate level that meet the economic value of customers while the company uses other attributes than price to achieve competitiveness (Reid \& Bojanic, 2009).

Similarly, several pricing techniques can be used for pricing tourist services. Cost-oriented pricing technique is a very popular pricing technique in the tourism industry according to which companies use the cost of product/service as an indicator to set the price. In other words, the product/service price needs to be high enough to cover costs (fixed and variable) and to achieve the desired profit margin. Accordingly, the selling price of products and services is the summation of costs and desired profit margin (Reid \& Bojanic, 2009). Using Cost-oriented pricing technique could result in over-pricing in low-demand seasons and underpricing in high demand seasons as production costs fluctuate according to sales volume (Hung, et al, 2010). Customer-oriented pricing technique considers the level of demand as a foundation for determining prices. It aims to maximize the price that customers are willing to pay based on the demand volume. So, when demand for a product and/or service is high, companies tend to set high prices (Reid \& Bojanic, 2009; Hung et al., 2010).

The competitive market structure represents a major issue in pricing (Chung, 2000). Competitiveoriented pricing technique utilizes price as a competitive tool through setting prices lower than competitors (Reid \& Bojanic, 2009; Abrate, et al, 2012). This technique could result in a significant decrease in prices to gain the desired market share which eventually reduces overall revenues and profits. It also can lead to general downturn in prices when competitors tend to match each other's' prices (Collin \& Parsa, 2006). Value-based pricing technique is another pricing technique according to which companies design and produce services and products at prices that meet the cost target requested by customers (Feldman \& Wurst, 2001). Through this technique, companies seek to maximize values provided to customers and reduce production costs to generate profits (Pinder, 2005). Thus, the right implementation of this technique depends on estimating the value of products and services for customers which can be misleading in many circumstances (Feldman \& Wurst, 2001).

Ending-pricing techniques, such as: "odd-ending"; "just-below"; "magic prices"; "charm prices"; "psychological prices"; "irrational prices"; "intuitive prices"; "or rule-of-thumb prices", exploit customer perception of the value of the price (Gendall, et al, 1997). These techniques lead customers to believe that the prices of products and services are below certain endings that do not reflect the real value of the prices, e.g. 299 instead of 300 (Huston \& Kamdar, 1996; Gendall et al., 1997). Yield Management (YM) pricing techniques are commonly adopted when distributors in the tourism sector set the prices (Sahut \& Hikkerova, 2009). YM pricing technique considers various parameters (such as: demand, cost, price, season, capacity) to set suitable prices for perishable services in order to maximize revenues (Koide \& Ishii, 2005). Last but not least, the differential-pricing technique attempts to set premium prices of products and services through using certain attribute of the product or service to persuade customers that these products/services are suitable (Namusonge, 2003).

Adopting a new pricing policy/technique is a critical issue that takes many factors into consideration, such as: applicability of the pricing technique, cost of applying the new pricing technique, management perception of the new pricing technique, organization needs for applying the new pricing technique, customer perception of the new pricing technique, experience and training of personnel, technical feasibility of the new pricing technique (Klein \& Loebbecke, 2003; Guo et al., 2013; Forbes, et al, 2014).

\section{Factors affecting pricing decision:}

There are several factors and issues that have a strong impact on the pricing process and shape the price of products and services. Such factors include: organizational and marketing objectives, costs of products and services. customers' expectations, competition and prices of the competitors, legal and regulatory issues, other variables of the marketing mix (i.e. product, place and promotion), volume of market demand, production capacity of the company, market conditions (Buhalis, 2000; Avlontis \& Indounas, 2007; Hudson, 2008; Barrows, et al, 2012, Kyurova, 2013). For example, Sahut and Hikkerova (2009) and Barrows et al. (2012) explained that in times of peak demand, prices tend to be at their maximum. Also, a limited capacity supports and raises price in season times (Barrows et al., 2012). 


\section{Efficiency of the pricing policy/technique:}

The effective pricing policy/technique should enable the organization to maximize profits, achieve the target rate of return on investment, reduce losses and obtain the desired market share (Hudson, 2008; Sangkaworn \& Mujtaba, 2010; Guo et al., 2013). Barrows et al. (2012) added that pricing technique should also enable the tourism enterprise to attract and maintain customers on the long-term not only generating revenues on the short-term. Kyurova (2013) further explained that pricing policy should help the organization to gain leadership in the market, obtain competitive advantage and survive tough times of the market.

(Guo et al. 2013) suggested that tourism enterprises can develop and apply optimal pricing policy through adopting market segmentation. According to Forbes, et al (2014), business managers can create and adopt an effective pricing policy through using comprehensive accumulation of information about the market combined with information about operations of the organization.

\section{Research methodology:}

A total of 65 questionnaire forms were distributed to tour operatoritravel agents ;but only 51 sales managers positively shared the interview at two of the major tourist cities in Egypt (Luxor and Hurghada). The gathered data was checked, coded, entered into SPSS for analysis. The questions aimed to evaluate the pricing techniques that are applied at Tour Operators/Travel Agents in Egypt. To achieve this purpose, a number of hypotheses have been tested during the present investigation:

- The pricing techniques that are applied at Tour Operators/Travel Agents have high levels of efficiency and sensitivity;

- Adoption of training programs influences significantly the efficiency of pricing techniques applied at Tour Operators/Travel Agents;

- There is a statistically significant correlation between the Sensitivity of pricing techniques and the efficiency of pricing techniques applied at Tour Operators/Travel Agents.

The questionnaire was designed to test these hypotheses and to identify the potential contextual factors that may influence the level of sophistication of pricing techniques at Tour Operators/Travel Agents in Egypt. The following contextual factors were examined:

1. Sensitivity of pricing techniques;

2. Efficiency of pricing techniques;

3. Obstacles of application of pricing techniques.

\section{Results and discussion}

This part shows the evaluation of pricing techniques that were applied at Tour Operators/Travel Agents.

Table (1): Reliability analysis of the independent variables used in the research

\begin{tabular}{|c|c|c|}
\hline The attribute & No. of statements & Alpha Coefficient \\
\hline Gender & 1 & Objective measure \\
\hline Experience & 1 & Objective measure \\
\hline Pricing training & 1 & Objective measure \\
\hline Pricing technique sensitivity & 7 & 0.8 \\
\hline Pricing technique efficiency & 5 & 0.78 \\
\hline $\begin{array}{c}\text { Obstacles of applying Pricing } \\
\text { technique }\end{array}$ & 3 & \\
\hline
\end{tabular}



level of 0.60 .

As mentioned in table (1), Alpha Coefficient for all variables was above the minimum acceptable

\section{Response Rate}

This study targeted the sales managers of 65 travel agents; only 51 sales managers positively shared the interview; this gave a response rate of (78 \%).

Table (2): Sample characteristics

\begin{tabular}{|c|c|c|c|}
\hline Variable & & No. & Percentage \\
\hline \multirow{2}{*}{ Gender } & Male & 30 & 58.8 \\
& Female & 21 & 41.2 \\
\hline \multirow{3}{*}{ Years of experience } & $1-5$ & 9 & 17.6 \\
& $6-10$ & 30 & 58.8 \\
& $11-15$ & 11 & 21.6 \\
\hline Applying pricing & $16-20$ & 1 & 2 \\
strategy & Yes & 48 & 94 \\
\hline \multirow{2}{*}{$\begin{array}{c}\text { Applying training } \\
\text { programs }\end{array}$} & No & 3 & 6 \\
\hline
\end{tabular}

From table (2) about $58.8 \%$ of the answers were taken from males, while $41.2 \%$ of the respondents were females. When looking at working years in Tour Operators/Travel Agents, the results indicated that $17.6 \%$ of the respondents had worked in the Tour Operators/Travel Agents for less than five years. On the other side, $58.8 \%$ of the respondents had worked for (6-10) years; finally, $2 \%$ of the sample had worked for more than 15 years. About $94 \%$ of respondents mentioned that they apply a pricing strategy at their companies, additionally, $86.3 \%$ of these companies follow training programs on pricing techniques for the employees.

Table (3): Descriptive Statistics

\begin{tabular}{|c|c|c|c|}
\hline Attribute & Mean & $\begin{array}{c}95 \% \text { Confidence } \\
\text { Interval for } \\
\text { Mean* }\end{array}$ & Attitude \\
\hline pricing strategy sensitivity & 4,4 & $4.3-4.5$ & Strongly agree \\
\hline $\begin{array}{c}\text { efficiency of pricing } \\
\text { strategy }\end{array}$ & 4,4 & $4.2-4.5$ & Strongly agree \\
\hline
\end{tabular}

95\% Confidence Interval for Mean of the study population $=\bar{X} \mp t .0 .025,55 *$ Std .Error

According to table (3), it is obvious that $95 \%$ Confidence Interval for the Mean of pricing strategy sensitivity is between $4.3-4.5$ and $95 \%$ Confidence Interval for the Mean of efficiency of pricing strategy is between 4.2 and 4.5. This means that pricing strategies applied at Tour Operators/Travel Agents have high levels of efficiency and sensitivity with $95 \%$ Confidence Interval for the means, and this result indicates that 
the pricing techniques applied at Tour Operators/Travel Agents has high levels of efficiency and sensitivity with 95\% Confidence Interval for the Means (the first hypothesis of the study is valid).

\section{Sensitivity of pricing techniques:}

The purpose of this question was to measure the sensitivity of the pricing technique in relation to some variables. The collected data is illustrated in table 4:

Table (4): Statistics for the sensitivity of pricing techniques applied at tour operators and travel agents.

\begin{tabular}{|c|c|c|c|c|}
\hline Item & M & SD & Sig. & Loadings \\
\hline Fluctuating demand & 4.9 & 0.91 & $0.000^{*}$ & 0.64 \\
\hline Time of year & 4 & 0.36 & 0.058 & 0.6 \\
\hline Type of tourist & 4.6 & 0.69 & $0.000^{*}$ & 0.75 \\
\hline Local competition & 4.1 & 0.81 & 0.129 & 0.6 \\
\hline Costs & 4.4 & 0.84 & $0.003^{*}$ & 0.7 \\
\hline Target profit & 4.2 & 0.72 & $0.04^{*}$ & 0.64 \\
\hline Owner desire & 4.4 & 0.75 & $0.000^{*}$ & 0.6 \\
\hline over all mean & 4.4 & 0.35 & $0.000^{*}$ & $64 \%$ \\
\hline
\end{tabular}

$\mathrm{M}=$ Mean SD = Standard Deviation Sig. = significance degree of one-sample T-Test

The analysis shown in table (4) indicates that all the seven items are loaded on a single factor and explain $64 \%$ of the variance in the underlying variable.

Table (4) shows that the overall mean of the variables is (4.4) and the standard deviation of mean values is (0.35), indicating high sensitivity of pricing techniques of these variables. The most effective variable is "Fluctuating demand", where the mean value is (4.9) and standard deviation (0.91). One-Sample T-test (with a test value (4)), this value was selected because it was a suitable value that referred to the degree of "agreement". In this case, p-values were divided into two types of results; the first type was statistically significant results where p-levels were definitely less than .05 (so, the null hypothesis was rejected); this result belongs to all variables except those of "Local competition " $(p=0.129)$ and " Time of year" (0.58)"; the result of these two variables represents the second type of results where p-level was definitely more than .05 ( so the null hypothesis of this variable was accepted).In other words, respondents' awareness of all variables equalled or exceeded the test value, coinciding with that the pricing techniques applied at Tour Operators/Travel Agents have high levels of efficiency and sensitivity with $95 \%$ Confidence Interval for Means(the first hypothesis of the study is valid)

\section{Efficiency of the pricing technique}

This question aimed to measure the efficiency of the pricing technique that is applied at Tour Operators/Travel Agents. The gathered data is illustrated in table (6).

Table (5): Statistics for the efficiency of pricing techniques applied at Tour Operators and Travel Agents. 


\begin{tabular}{|c|c|c|c|c|}
\hline Item & M & SD & Sig. & Loading \\
\hline $\begin{array}{c}\text { 1- Pricing technique covers both direct } \\
\text { and indirect costs. }\end{array}$ & 4.9 & 0.14 & $\begin{array}{c}0.000 \\
*\end{array}$ & 0.604 \\
\hline $\begin{array}{c}\text { 2- Pricing technique deals with marketing } \\
\text { competition. }\end{array}$ & 3.7 & 0.46 & $\begin{array}{c}0.003 \\
*\end{array}$ & 0.608 \\
\hline 3- Pricing interest in tourist psychology. & 4.4 & 1.2 & $\begin{array}{c}0.035 \\
*\end{array}$ & 0.78 \\
\hline $\begin{array}{c}\text { 4- Pricing aims to achieve the highest } \\
\text { level of profitability. }\end{array}$ & 4.1 & 0.71 & $\begin{array}{c}0.322 \\
*\end{array}$ & 0.603 \\
\hline $\begin{array}{c}\text { 5- Pricing interest in the quality of } \\
\text { products and services. }\end{array}$ & 4.5 & 0.68 & $\begin{array}{c}0.000 \\
*\end{array}$ & 0.6 \\
\hline Over all mean & 4.3 & 0.423 & 0.000 & $64 \%$ \\
\hline
\end{tabular}

$\mathrm{M}=$ Mean SD = Standard Deviation Sig. = significance degree of one-sample T-Test

Table (5) declares that all the five items were loaded on a single factor explain $64 \%$ of the variance in the underlying variable. The same table also indicates that the highest variable that relate to the principal factor is "Pricing interest in tourist psychology" with a loading level of $(0.78)$, On the other hand the lowest variable that relate the principal factor is "Pricing interest in the quality of products and services." with loading level (0.6).

Again table (5) indicates that the overall mean of the above motioned variables is (4.3) and the standard deviation of mean values is $(0.423)$ which indicates the average efficiency of the pricing techniques. The most effective variable is "Pricing technique covers both direct and indirect costs ", where the mean value is (4.9) and standard deviation (0.14). One-sample T-test (with a test value of (4)) indicates a statistical significant difference between respondents' awareness of all variables and the test value except the variable of "Pricing aim to achieve the highest level of profitability" $(\mathrm{p}=0.322)$ where $\mathrm{p}$-level is definitely more than .05 (so the null hypothesis of this variable is accepted). This result reflects that respondents' awareness of most variables exceeded the test value, and thus coincides with that the first hypothesis of the study is valid.

Testing of the second Hypothesis requires the use of simple regression analysis to examine the interaction of selected variables.

Table (6), Simple regression of adoption of training programs on the efficiency of pricing techniques

\begin{tabular}{|c|c|c|c|c|c|c|c|c|c|c|}
\hline Statement & R & R2 & $\begin{array}{c}\text { Adjusted } \\
\text { R2 }\end{array}$ & F & Sig. & T & Sig. & Beta & \multicolumn{2}{|c|}{$\begin{array}{c}\text { Unstandardized } \\
\text { coefficient }\end{array}$} \\
\cline { 5 - 10 } & & & & & & 6.099 & 0.00 & & 2.6 & 0.437 \\
\hline $\begin{array}{c}\text { pricing } \\
\text { training }\end{array}$ & 0.5 & 0.25 & 0.232 & 15.18 & 0.00 & 3.89 & 0.00 & 0.498 & 0.87 & 0.224 \\
\hline
\end{tabular}


To predict the goodness-of-fit of the regression model, the correlation coefficient (R), coefficient of determination (R2), and F ratio were examined. First, $(\mathrm{R})$ value $(0.5)$ referred to a moderate degree of correlation between the efficiency of pricing techniques and the adoption of training programs at Tour Operators/Travel Agents. Secondly, the (R2) is 0.25 , suggesting that $25 \%$ of the variation of the efficiency of pricing techniques was explained by the adoption of training programs. Lastly, the F ratio, which explains whether the results of the regression model could have occurred by chance, had a value of $15.18(\mathrm{p}=0.00)$ and was considered significant. The regression equation is as follows:

Efficiency of pricing technique $=2.6+0.87$ the adoption of training programs, these results proved that the second hypothesis of the study is correct.

Table (7), Correlation coefficient between Sensitivity of pricing techniques and efficiency of pricing techniques

\begin{tabular}{|l|l|l|}
\hline Variable & $\begin{array}{l}\text { Efficiency of } \\
\text { pricing technique }\end{array}$ \\
\hline Sensitivity of pricing techniques & $\begin{array}{c}\text { Pearson Correlation } \\
\text { Sig. (2-tailed) } \\
\text { No. }\end{array}$ & $\begin{array}{l}0.49 \\
0.000 \\
48\end{array}$ \\
\hline
\end{tabular}

Table (7) indicated that Sensitivity of pricing techniques had a moderate degree of correlation with the efficiency of pricing techniques(PT) at Tour Operators/Travel Agents, as their correlation coefficient was 0.49 (between 0.40 and 0.60 ) and found to be statistically significant factors where the significance level was less than 0.05 . This means that there is an effect of Sensitivity of pricing techniques on the efficiency of PT. These results coincide with the third hypothesis of the study( a statistically significant correlation between the Sensitivity of pricing techniques and the efficiency of pricing technique applied at Tour Operators/Travel Agents) is correct.

\section{Obstacles that hinder pricing techniques that applied on Tour Operators and Travel Agents}

This question aimed to ascertain the difficulties that delay the adoption of pricing techniques at Tour Operators/Travel Agents. The gathered data is illustrated in table (8).

Table (8): Statistics for the obstacles that limit the application of pricing techniques at Tour Operators/Travel Agents

\begin{tabular}{|c|c|c|c|c|}
\hline Item & $\mathrm{M}$ & $\mathrm{SD}$ & Sig. & Loadings \\
\hline $\begin{array}{c}\text { 1-High costs of using modern } \\
\text { pricing technique }\end{array}$ & 4.9 & 0.45 & $\begin{array}{c}0.000 \\
*\end{array}$ & 0.999 \\
\hline 2-Incompetence of marketing staff & 3.8 & 0.55 & $\begin{array}{c}0.044 \\
*\end{array}$ & 0.795 \\
\hline 3-Management. & 4.1 & 1.03 & 0.272 & 0.874 \\
\hline over all mean & 4.3 & 0.49 & $\begin{array}{c}0.000 \\
*\end{array}$ & $91.5 \%$ \\
\hline
\end{tabular}

According to table (8) it can be found that all the three items loaded on a single factor explained 91.5\% of the variance in the underlying variable. "High costs of using modern pricing technique" was the higher variable that relate to the principal factor with a loading level of (0.999). On the other hand the lowest variable that relate to the principal factor was "Incompetence of marketing staff" variable with a loading level of (.795). 
Table (8) indicates that the overall mean of the above variables was (4.3) and the standard deviation of the means values was (0.49) which indicates a high participation of these obstacles as barriers impeding pricing techniques adoption in the Tour Operators/Travel Agents. One-Sample T-test (with a test value of (4)) implies a statistical significant difference between respondent's awareness of the variables and the test value, except the variable of "Management" where the significance level above 0.05.

\section{Conclusion:}

The results of this study referred to the fact that more than $86 \%$ of Tour Operators/Travel Agents follow training programs of pricing techniques for their employees. There was a strong relation between the efficiency of pricing techniques and the adopting of training programs at Tour Operators/Travel Agents, and there was a statically significant correlation between the sensitivity of the pricing techniques and the efficiency of pricing techniques applied at Tour Operators/Travel Agents, and the most effective variable of the sensitivity of pricing techniques was "Fluctuating demand".

\section{Recommendations:}

It is very important to the managers of Tour Operators and Travel Agents to know the correct application of pricing policies and their techniques which help present competitive opportunities to their companies. Also important is the interaction between the different factors of the marketing mix(productplace-promotion)and the pricing factor to get the competitive edge.

Training of employees on modern pricing techniques, and pricing policies should be periodically reviewed to make sure that there are no problems facing Tour Operators and Travel Agents during and after the tourist service, besides applying the suitable pricing policies for Tour Operators/Travel Agents' conditions, and using all information to improve the knowledge of those engaged in marketing.

-Tour Operators and Travel Agents should change their pricing policies according to tourism market conditions; and set prices that cover fixed and variable costs regardless of pricing policies they apply.

Pricing policies should be flexible and allow change in the frame of a number of alternatives that could be easily achieved to face changeable circumstances.

Tour Operators and Travel Agents should take in consideration many elements when planning pricing policies, and one of the most important elements or factors is the effect of price on the psychology of the tourist, and also the quality of product and services, and the international tendencies to limit its role when putting prices,

Managers of Tour Operators and Travel Agents should face Obstacles that hinder applying new pricing policies, specially the high cost, and pay more attention to training and graduating technical staff in different specialties.

\section{References:}

1. Abrate, G.; Fraquelli, G., and Viglia, G. (2012). Dynamic pricing strategies: evidence from European hotels. International Journal of Hospitality Management, 31(1), 160-168.

2. Avlontis, G., and Indounas, K. (2007) an Empirical Examination of the Pricing Policies and their Antecedents in the Services Sector. European Journal of Marketing, 41 (7/8) 740-764.

3. Aziz, H. A.; Saleh, M., Rasmy, M.; H. and ElShishiny, H. (2011). Dynamic room pricing model for hotel revenue management systems. Egyptian Informatics Journal, 12(3), 177-183.

4. Barrows, C. W., Powers, T. and Reynolds, D. (2012). Introduction to Management in the Hospitality Industry, 10th edition. John Wiley \& Sons: USA.

5. Buhalis, D. (2000). Marketing the competitive destination of the future. Tourism management, 21(1), 97-116.

6. Chung, K. Y. (2000). Hotel room rate pricing strategy for market share in oligopolistic competition-eight-year longitudinal study of super deluxe hotels in Seoul. Tourism Management, 21(2), 135-145. 
7. Collins, M., and Parsa, H. G. (2006). Pricing strategies to maximize revenues in the lodging industry. International Journal of Hospitality Management, 25(1), 91-107.

8. Feldman, D., and Wurst, J., (2001) Optimal pricing through value modelling, Journal of Professional Pricing, 10 (2)31-33.

9. Forbes, K., Berthur, M., and Sebastian, V. (2014) Pricing and domestic tourism performance in Zimbabwe. African Journal of Hospitality, Tourism and Leisure, 3 (2), 1-12.

10. Gazopoulou, E. (2012). A note on the effectiveness of price policy on tourist arrivals to Greece. Bank OF Greece, Economic Research Department - Special Studies Division Working paper (No. 144).

11. .Gendall, P.; Holdershaw, J., and Garland, R. (1997). The effect of odd pricing on demand. European Journal of Marketing, 31(11/12), 799-813.

12. Guo, X.; Ling, L.; Yang, C.; Li, Z., and Liang, L. (2013). Optimal pricing strategy based on market segmentation for service products using online reservation systems: An application to hotel rooms. International Journal of Hospitality Management, 35, 274-281.

13. Hudson, S. (2008). Tourism and hospitality marketing: a global perspective. Sage. USA.

14. Hung, W. T.; Shang, J. K., and Wang, F. C. (2010). Pricing determinants in the hotel industry: Quantile regression analysis. International Journal of Hospitality Management, 29(3), 378-384.

15. Huston, J., and Kamdar, N. (1996). \$9.99: Can" Just-Below" Pricing Be Reconciled with Rationality? Eastern Economic Journal, 137-145.

16. Klein, S., \& Loebbecke, C. (2003). Emerging pricing strategies on the web: lessons from the airline industry. Electronic Markets, 13(1), 46-58.

17. Koide, T., and Ishii, H. (2005). The hotel yield management with two types of room prices, overbooking and cancellations. International Journal of Production Economics, 93, 417-428.

18. Kyurova, V. (2013). Opportunities For Improvement Of The Pricing Policy Of Travel Agencies In Cultural Tourism. Romanian Economic and Business Review, 81.

19. Lancaster, G., and Reynolds, P. (2005). Management of marketing. Routledge, Oxford.

20. Namusonge, M. (2003). Linking competencies with strategy: the case of small and medium-sized exporting firms in Kenya. 2003 (Doctoral dissertation, University of Illinois at Urbana-Champaign).

21. Pinder, J. (2005). Using revenue management to improve pricing and capacity management in programme management. Journal of the Operational Research Society, 56(1), 75-87.

22. Reid, R. D., and Bojanic, D. C. (2009). Hospitality marketing management. John Wiley and Sons.

23. Sahut, J. M. and Hikkerova, L. (2009). The impact of internet on pricing strategies in the tourism industry. Journal of Internet Banking and Commerce,14 (1), 1-8.

24. Sangkaworn, C. and Mujtaba, B. G. (2010) Marketing practices of hotels and resorts in Chiang Mai: a study of products, pricing, and promotional practices. Journal of Management and Marketing Research, 4(1), 165-183.

25. Walpole, M. J.; Goodwin, H .J. and Ward, J. G. R. (2008) Lessons from Komodo National Park, Indonesia, Conservation Biology, 15 (1) 218- 227.

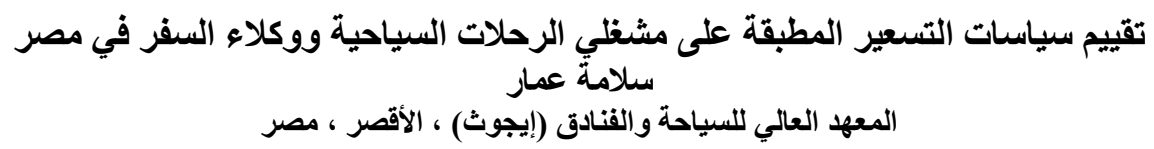

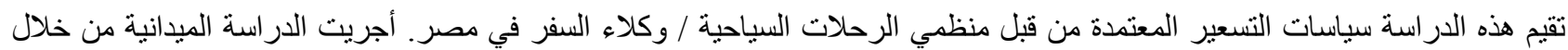
توزيع استبيان على مديري منظمي الرحلات السياحية / وكلاء السفر. شملت العينة 51 من مشغلي الرحلات السئلئ السياحية / مديري وكلاء السفر. 
تتمتع تقنيات التسعير المطبقة لدى مشغلي الرحلات السياحية / وكلاء السفر بمستويات عالية من الكفاءة والحساسية ، وتؤثر البر امج التدربيية

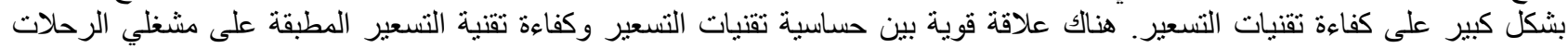

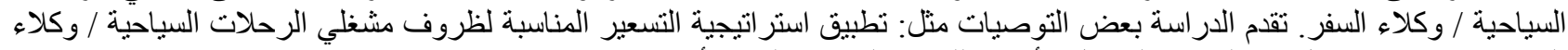

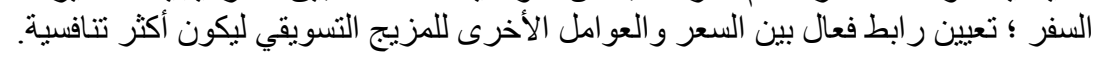

